\title{
Priming Soilless Growing Medium with Disaccharides Stimulated Microbial Biofilm Formation, and Increased Particle Aggregation and Moisture Retention during Muskmelon Transplant Production
}

\author{
Gregory E. Welbaum ${ }^{1}$, Zhen-Xing Shen, and Jonathan I. Watkinson \\ Department of Horticulture, Saunders Hall, Virginia Tech, Blacksburg, VA 24061 \\ Chun-Li Wang \\ Department of Plant Industry, National Pingtung University of Science and Technology, 1 Hseuh Fu \\ Road, Nei Pu Hsiang, Pingtung, Taiwan 291207, Republic of China \\ Jerzy Nowak \\ Department of Horticulture, Saunders Hall, Virginia Tech, Blacksburg, VA 24061
}

\begin{abstract}
AdDitional INDEX words. sucrose, trehalose, Bacillus, Curtobacterium pussillum, Paenibacillus lautus, Brevundimonas, Cucumis melo

Abstract. Priming commercial growing media and soils with dilute sugar solutions was investigated as a means of stimulating beneficial microflora to improve transplant productivity. Muskmelon (Cucumis melo) seedlings were grown in soilless growing medium primed with equal volumes of 50 mм sucrose or trehalose. After priming, the time when $50 \%$ of plants showed wilting symptoms was delayed 45 hours and the mean time that seedling xylem tension reached -1.0 MPa was delayed 70 hours compared with watered controls. Sucrose or trehalose priming improved water retention in the presence and absence of plants grown in sphagnum-based medium after an incubation period of $\approx \mathbf{2 4}$ h, but no improvement occurred when autoclaved medium or acid-washed sand were primed. Light micrographs of primed medium revealed positive staining of opaque material between organic-matter particles with alcian blue, a polysaccharide-specific stain. Sixteen bacterial colonies were cultured in liquid medium from leachate of positivestained, primed, growing-medium samples and identified via 16S rRNA gene sequencing. Identified colonies were Curtobacterium pussillum, Paenibacillus lautus, Brevundimonas, and 13 Bacillus spp., including well-characterized biofilm producers. Increased soil-moisture retention was the result of a complex, glucose-based, hydrophilic, polysaccharide polymer of bacterial origin that was produced in liquid culture from extracts of primed medium.
\end{abstract}

Beneficial soil microorganisms play a key role in maintaining soil quality and health (Karlen et al., 1997; Pankhurst et al., 1997). Microbial activity in soils is stimulated by the release of carbon-rich material in the form of root border cells (Hawes and Brigham, 1992; Hawes et al., 1998), and/or the selective exudation of specific sugars, carboxylic acids, or amino acids (Grayston et al., 1998; Lugtenberg et al., 2001; Ryan et al., 2001; Siciliano et al., 1998) that encourage the development of cultivar-specific, plant-beneficial, microbial communities (Chanway et al., 1988; Lugtenberg et al., 2001; Marschner et al., 2004). During transplant production, selective exudation takes place only after seed germination and root system development. Without growing plants, soil microorganisms can survive for long periods of time as primarily dormant populations (Mondini et al., 2006). They respond rapidly to addition of fresh energy [i.e., sucrose (Kelliher et al., 2005) or glucose (Mondini et al., 2006)]. This new energy source enhances microbial growth and humification of soil organic

Received for publication 3 Oct. 2008. Accepted for publication 3 Apr. 2009. We thank Novozymes Inc. for assistance with bacterial analysis, M. Wood and M. Ponder for assistance with manuscript preparation, and R. Helm for assistance with carbohydrate analysis.

${ }^{1}$ Corresponding author. E-mail: welbaum@vt.edu. matter, which in turn improves the mineral- and water-holding capacity of soil. This process is recognized in the literature as soil priming (reviewed in Blagodatskaya and Kuzyakov, 2008).

Some of the bacteria benefiting from the availability of fresh energy are also capable of activating defense responses, making plants more resistant to abiotic and biotic stresses (reviewed in Conrath et al., 2006). This phenomenon, referred to as biopriming, is being adapted to vegetative propagation of high-value crops via tissue culture (reviewed in Nowak and Schulaev, 2003). Plantlets inoculated with selected strains of endophytic bacteria can acquire resistance to transplanting shock, as well as to some fungal and viral diseases (reviewed in Kavino et al., 2007; Nowak and Schulaev, 2003).

Soils can be primed by using cover crops to include "primer plants," which support establishment of soil microbial communities (Yunusa and Newton, 2003). Roots of plants used to prime soil penetrate deep into subsoil and secrete sugars to create and sustain symbioses with microbes that benefit plant growth and development (Wardle, 2002). However, organic compounds released from living plants or decomposing plant material may be insufficient to sustain or optimize the proliferation of beneficial soil microbes (Welbaum et al., 2004).

Despite considerable research describing microbial population changes in soil and plant rhizosphere (reviewed in 
Welbaum et al., 2004), little is known about plant-microbial interactions that occur in soilless growing media during bedding-plant production. We hypothesize that in transplant production systems, beneficial microbial colonies may be slow to develop and could be stimulated by soil priming with carbon sources. Priming of the growing medium in this context is defined as improving its "readiness" to receive a selected crop. Using plants to prime germination medium before transplant production is not an option. However, priming soils by applying specific carbon amendments tailored to stimulate beneficial microbes may benefit transplant production by increasing growth and improving survivability in the field. Soil priming with natural compounds would be compatible with organictransplant-production guidelines.

Glucose amendments have successfully increased microbial activity in field soils (Hoyle et al., 2008; Schenkenberger et al., 2008). In this study, we investigate the priming of commercial soilless growing medium with trehalose (a disaccharide comprised of two glucose units, $\mathrm{C}_{12} \mathrm{H}_{22} \mathrm{O}_{11}, \alpha$-D-glucopyranosyl $\alpha$-D-glucopyranoside) and sucrose [a disaccharide comprised of glucose and fructose, $\mathrm{C}_{12} \mathrm{H}_{22} \mathrm{O}_{11}, \alpha$-D-glucopyranosyl( $1 \leftrightarrow 2)-\beta$-D-fructofuranoside] to produce seedlings with increased drought stress resistance. Trehalose was chosen because of its regulatory role in plants (Koch, 1996; León and Sheen, 2003; Smeekens, 2000), including reducing succulent growth of transplants (Shen and Welbaum, 2004). Sucrose was selected as an inexpensive carbon source that is used by a variety of soil bacteria.

\section{Materials and Methods}

Plant material and soil analysis. Muskmelon seeds (cv. Top Mark; Monsanto, St. Louis) were planted in black plastic transplant trays, $[12$ cells, $4 \mathrm{~cm}($ length $) \times 3 \mathrm{~cm}($ width $) \times 5.5 \mathrm{~cm}$ (depth), $60 \mathrm{~cm}^{3}$ per cell], equally filled with soilless growing medium (Sunshine Mix I, coarse sphagnum moss and perlite; Fissons, Vancouver, BC, Canada). For priming studies, equivalent volumes of vermiculite (particle diameter $1.5 \mathrm{~mm}$, Tobacco Mix; Southern States, Richmond, VA), acid-washed sand (Sigma, St. Louis), or Hayter loam (fine-loamy, mixed, mesic Ultic Hapludalf) field soil collected near Blacksburg, VA, were sieved $(2.4 \mathrm{~mm})$, air dried for $2 \mathrm{~d}$ at room temperature, added to three 12-cell plastic trays per treatment, and tested in a growth chamber (Percival Scientific, Boone, IA). Soilless growing medium was autoclaved $\left(134{ }^{\circ} \mathrm{C}, 200 \mathrm{kPa}\right.$, 20 min steam cycle) before treatment to compare moistureretention patterns of steam-treated and nontreated samples. During and after priming, soilless medium, vermiculite, and soil water contents were measured by drying samples at $98{ }^{\circ} \mathrm{C}$ for 24 to $48 \mathrm{~h}$ and results are expressed as a percentage of the soil dry weight (fresh weight - dry weight/dry weight $\times 100$ ). Effects of priming with $50 \mathrm{~mm}$ sucrose solution on the waterretention capacity of three samples each of primed and nonprimed media were compared using a soil pressure plate (Soil Moisture Equipment, Santa Barbara, CA) after equilibration at 0.5 and $1.5 \mathrm{MPa}$. Analysis of variance was performed on pressure-plate medium moisture retention values and means were separated by least significant difference $(P<0.05)$. The Virginia Tech Soil Testing Laboratory (Blacksburg, VA) analyzed chemical properties of soilless growing media initially before treatments were applied.
In the initial growth-chamber study with air-dry soilless growing medium, muskmelon seeds were sown one per tray cell and hydrated with $20 \mathrm{~mL}$ of water or 15 or $50 \mathrm{~mm}$ trehalose solution and were incubated for $7 \mathrm{~d}$ without additional water. To assess the effect of priming on medium moisture retention, $50 \mathrm{~mm}$ sucrose or trehalose was added to air-dried soilless growing medium in replicates of four 12-cell trays each in a separate experiment. To evaluate concentration and possible toxic effects of sucrose, three 12-cell trays of soilless growing medium were watered or primed with $20 \mathrm{~mL}$ of 0,1 , or 10 to $90 \mathrm{~mm}$ sucrose in $10 \mathrm{~mm}$ increments. Moisture loss was quantified by weighing samples after watering air-dried medium. Wilting symptoms, loss of turgor causing leaves of four replications of 21-d-old plants (two to three true leaves) to drop to an angle at least $45^{\circ}$ below the main stem, and seedling xylem tension were measured on four replications of 10-d-old plants each and three replications of 21-d-old plants (two- to three-leaf stage) using a pressure chamber (Soil Moisture Equipment, Santa Barbara, CA), 0 to $300 \mathrm{~h}$ after solution application. Growthchamber experiments were conducted under a 16-h photoperiod, constant $25^{\circ} \mathrm{C}$, and light intensity of $50 \mu \mathrm{E}^{-1} \cdot \mathrm{m}^{-1} \cdot \mathrm{s}^{-1}$, using two, three, or four replicates of 12 plants each organized in a completely randomized design.

BACTERIAL ISOLATION AND POLYSACCHARIDE PRODUCTION IN CULTURE. Bacteria were isolated from soilless growing medium primed with $50 \mathrm{~mm}$ sucrose by mixing $1 \mathrm{~g}$ of medium with $15 \mathrm{~mL}$ of sterile water and collecting the supernatant. Serial dilutions $\left(10^{2}-10^{5}\right.$ times) of the supernatant were plated on tryptic soy agar (TSA) enriched with $50 \mathrm{~mm}$ sucrose. The opaque exudate that surrounded some colonies was tested for carbohydrate using alcian blue $\left(\mathrm{C}_{56} \mathrm{H}_{68} \mathrm{Cl}_{4} \mathrm{CuN}_{16} \mathrm{~S}_{4}\right)$, which stains sulfated and carboxylated mucopolysaccharides, glycosaminoglycans, and sulfated and carboxylated glycoproteins (Powell et al., 1982). Prominent colonies were subcultured in $25 \mathrm{~mL}$ of semisynthetic liquid medium to assess polysaccharide production as described by Bruegger and Keen (1979) with potassium phosphate $(0.05 \mathrm{M})$ substituted for yeast extract and $50 \mathrm{~g} \cdot \mathrm{L}^{-1}$ sucrose. After incubation at $25^{\circ} \mathrm{C}$ for $3 \mathrm{~d}$ with agitation at $90 \mathrm{rpm}$, cells were harvested by centrifugation $\left(7800 g_{\mathrm{n}}, 15\right.$ $\mathrm{min}$ ), washed with $5 \mathrm{~mL}$ of sterile water, and resuspended. The suspension was precipitated in $1 \%(\mathrm{w} / \mathrm{v}) \mathrm{KCL}$ with ice-cold ethanol (three to four volumes), vigorously mixed in $5 \mathrm{~mL}$ of distilled water for $2 \mathrm{~min}$, and insoluble material was removed by centrifugation $\left(17,000 \mathrm{~g}_{\mathrm{n}}, 15 \mathrm{~min}\right)$.

Carbohydrate analysis and staining. Medium samples were suspended in phosphate buffer $(\mathrm{pH} 7)$ 1:100 (w/v) for 15 min and a $3-\mathrm{mL}$ aliquot containing medium particles was transferred to a $140-\mathrm{mm}$-diameter petri plate. A $1 \%$ alcian blue solution in ethanol was diluted to $0.1 \%$ with water, and several drops were pipetted onto each sample. After $3 \mathrm{~min}$, the stain was rinsed with phosphate buffer, drained, and viewed by light microscopy.

For carbohydrate analyses, polysaccharides $(10 \mu \mathrm{g})$ were isolated from solution culture by a two-step lysis (methanolysis followed by trifluoroacetic acid hydrolysis) to release monosaccharides and uronic acids (Talaga et al., 2002). Quantitative external standard analyses were performed in duplicate on five different polysaccharide isolates. Chromatographic separation and data analysis were performed using a liquid chromatography system (Dionex, Sunnyvale, CA) consisting of a LC30 oven, GP50 pumps, an ED50 pulsed amperometric detector, and PeakNet software (Dionex). Separations were performed 
with a $4 \times 250-\mathrm{mm}$ column (Carbopac PA10, Dionex) and a $4 \times$ 50-mm guard column (Talaga et al., 2002). Mass spectral analysis of the hydrolyzates was performed by direct-infusion electrospray ionization (Thermo Finnigan DecaXP; Thermo Scientific, San Jose, CA). Hydrolyzate was dissolved in methanol:water $(1: 1 ; \mathrm{v} / \mathrm{v})$ and infused at a flow of $5 \mu \mathrm{L} / \mathrm{min}$. Spray voltage was $4.5 \mathrm{kV}$ (negative mode) with a capillary temperature of $225^{\circ} \mathrm{C}$. The mass range was 100 to $2000 \mathrm{~m} / \mathrm{z}$.

BaCterial Genetic anAlysis. Genetic analysis of bacterial colonies (MIDI Laboratories, Newark, DE) from TSA was by cycle sequencing of the $16 \mathrm{~S}$ rRNA amplification products with AmpliTaq FS DNA polymerase and dRhodamine dye terminators (Kolbert and Pershing, 1999; Patel et al., 2000). Two separate primer sets (5F and 531R) amplified 16S rRNA genes to produce 500-bp products. Amplification products were purified from excess primers and dNTPs (deoxyribonucleotide triphosphates) using molecular weight cut-off membranes (Microcon 100; Millipore, Bedford, MA) and were run on an agarose gel to control quality and quantity. Excess dye-labeled terminators were removed from sequencing reactions using a spin column (Sephadex G-50; Amersham Pharmacia Biotech, Piscataway, NJ). The sequencing products were collected by centrifugation, dried under vacuum, and frozen at $-20{ }^{\circ} \mathrm{C}$ until loading. Sample electrophoresence was performed using a DNA Sequencer (ABI Prism 377; Applied Biosystems, Carlsbad, CA), and the data were analyzed with DNA editing and assembly software (Applied Biosystems). Edited and assembled DNA sequences were identified based on pairwise alignment algorithms and phylogenetic trees with MicroSeq Analysis Software and Sequence Database (Applied Biosystems).

\section{Results}

Priming commercial soilless growing medium with $50 \mathrm{~mm}$ trehalose reduced cumulative water loss between 25 and $260 \mathrm{~h}$ (Fig. 1A). At 25 h, there was only a small difference between trehalose-primed and nonprimed (watered) soilless growing medium. This difference increased and was largest between 100 and $150 \mathrm{~h}$ before reaching parity at $285 \mathrm{~h}$ (Fig. 1A).

The xylem tension of muskmelon seedlings grown in nonprimed or trehalose-primed growing medium was similar until $125 \mathrm{~h}$ (Fig. 1B). After $125 \mathrm{~h}$, the xylem tension of muskmelon seedlings in nonprimed growing medium abruptly increased. In contrast, the xylem tension of seedlings in trehalose-primed growing medium did not change between 125 and $150 \mathrm{~h}$ (Fig. 1B).

Similarly, more plants wilted after $125 \mathrm{~h}$ in nonprimed growing medium (Fig. 1C). The time for $50 \%$ of muskmelon seedlings to show wilting symptoms was delayed $45 \mathrm{~h}$ in growing medium primed with $50 \mathrm{~mm}$ trehalose (Fig. 1C). Muskmelon plants grown in soilless medium primed with $50 \mathrm{~mm}$ trehalose resisted wilting longer than nonprimed or medium primed with $15 \mathrm{~mm}$ trehalose, even though all treatments were hydrated with equal volumes of liquid (Fig. 2).

Dried medium samples differed in appearance following priming with sucrose (Fig. 2, inset) or trehalose (not shown). Dried sucrose-primed soilless growing medium maintained tray-cell shape as a solid block when removed from cells, while dried nonprimed growing medium crumbled (Fig. 2, inset).

The $\mathrm{pH}$ of nonprimed soilless growing medium was 6.7 and the percentage of organic matter was $67.3 \%$, while the cation

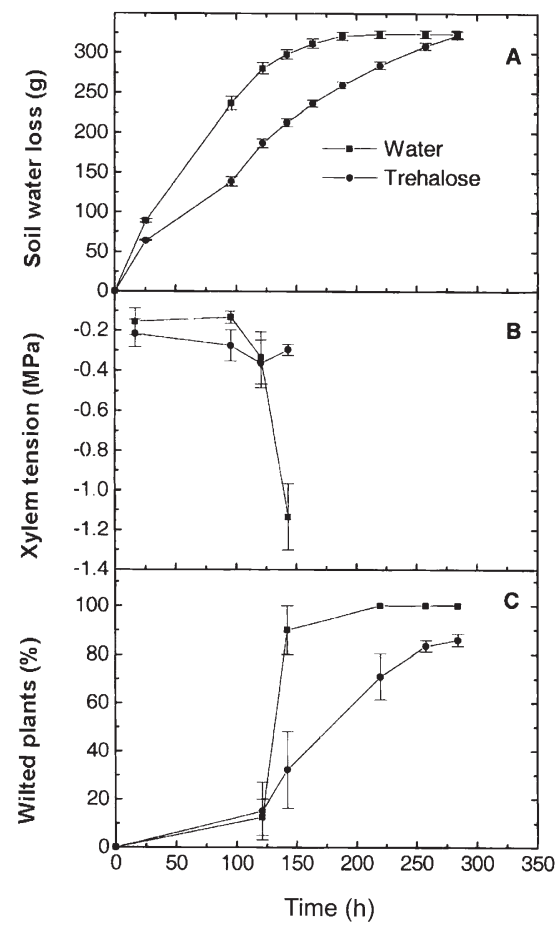

Fig. 1. Cumulative water loss from plug trays filled with equal volumes of soilless growing medium (Sunshine Mix I; Fissons, Vancouver, BC, Canada) primed with $20 \mathrm{~mL}$ of $50 \mathrm{~mm}$ trehalose or water in a growth chamber. Error bars represent \pm SE of four replications of 12 plants each for each time interval (A). Muskmelon seedling xylem tension time courses for 21-d-old plants (two- to three-leaf stage) measured for three plants at each time point with a pressure chamber after an initial application with $20 \mathrm{~mL}$ of $50 \mathrm{~mm}$ trehalose or water (B). Development of wilting symptoms of four replications of 21-d-old plants after $20-\mathrm{mL}$ solutions of water or $50 \mathrm{~mm}$ trehalose were applied to individual tray cells. (C) Error bars represent $\pm \mathrm{SE}$.

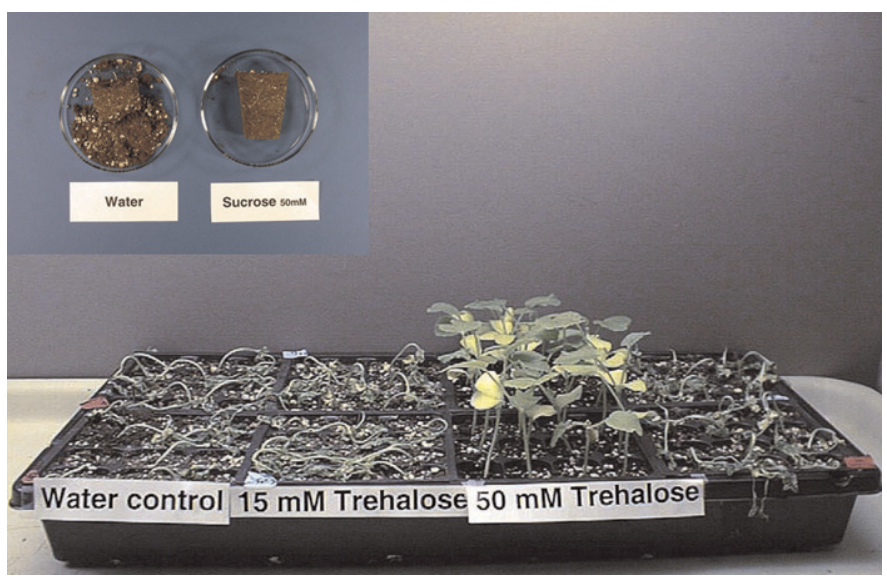

Fig. 2. Twenty-one-day-old muskmelon seedlings were grown in a growth chamber in soilless growing medium (Sunshine Mix I; Fissons, Vancouver, $\mathrm{BC}$, Canada) for $72 \mathrm{~h}$ following a single treatment with $8 \mathrm{~mL}$ of water, or 15 or $50 \mathrm{~mm}$ trehalose. Similar results were obtained following treatment with sucrose. Two replications of 12 plants each are shown for each treatment and are representative of similar experiments conducted. Inset shows that medium treated with $50 \mathrm{~mm}$ sucrose retained cell shape when air-dried while watered media did not. Similar results were obtained following treatment with trehalose. (Please view this paper online at ashs.org to see the image in color.) 
exchange capacity was $7.3 \mathrm{cmol} \cdot \mathrm{kg}^{-1}$. The mineral composition of nonprimed soilless growing medium was $15.5 \mathrm{mg} \cdot \mathrm{kg}^{-1}, 55.0$ $\mathrm{mg} \cdot \mathrm{kg}^{-1}, 801 \mathrm{mg} \cdot \mathrm{kg}^{-1}$, and $377 \mathrm{mg} \cdot \mathrm{kg}^{-1}$ for $\mathrm{P}, \mathrm{K}, \mathrm{Ca}$ and $\mathrm{Mg}$, respectively (data not shown).

Between 75 and $150 \mathrm{~h}$, the moisture content of growing medium was nearly identical in sucrose- or trehalose-primed medium, illustrating that the improvement in moisture retention could be obtained using either disaccharide (Fig. 3A). Plants were under less moisture stress in growing medium primed with sucrose or trehalose during the first $200 \mathrm{~h}$ compared with nonprimed medium that received only water (Fig. 3B). The time to reach $-1.0 \mathrm{MPa}$ was delayed $70 \mathrm{~h}$ in primed growing medium compared with nonprimed (Fig. 3B).

Growing medium primed with $10 \mathrm{~mm}$ or greater concentrations of sucrose maintained the highest water content from 48 to $120 \mathrm{~h}$, while priming with $1 \mathrm{~mm}$ sucrose solution had the same effect as applying only water (Fig. 4A). Applications of 20 to $50 \mathrm{~mm}$ sucrose solutions resulted in the highest potting-medium-moisture contents over this period. Growing-medium-moisture contents, similar to the $50 \mathrm{~mm}$ treatments, were obtained using 60 to $90 \mathrm{~mm}$ sucrose solutions (not shown).

The moisture-retention patterns of soilless growing medium treated with water or primed with $50 \mathrm{~mm}$ sucrose were compared on a pressure plate. Soilless growing medium pressurized to 0.4 or $1.5 \mathrm{MPa}$ retained significantly more water in primed compared with nonprimed samples treated with equal volumes of water (Table 1).

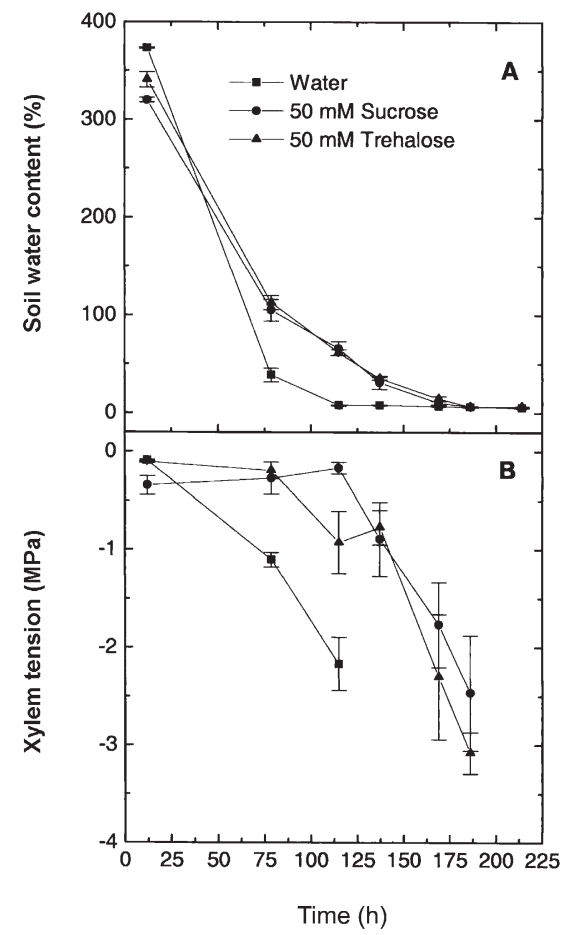

Fig. 3. Changes in soilless growing medium (Sunshine Mix I; Fissons, Vancouver, BC, Canada) moisture content following priming with $8 \mathrm{~mL}$ of water, $50 \mathrm{~mm}$ sucrose, or $50 \mathrm{~mm}$ trehalose. Growing medium moisture contents were determined from fresh and oven dry weights of medium from four 12-cell trays (A). Pressure-bomb measurements of 10-d-old (postemergence) seedling xylem tensions from destructively harvested plants grown in soilless growing medium primed with sucrose or trehalose. Error bars represent \pm SE of four replications at each time point $(\mathbf{B})$.

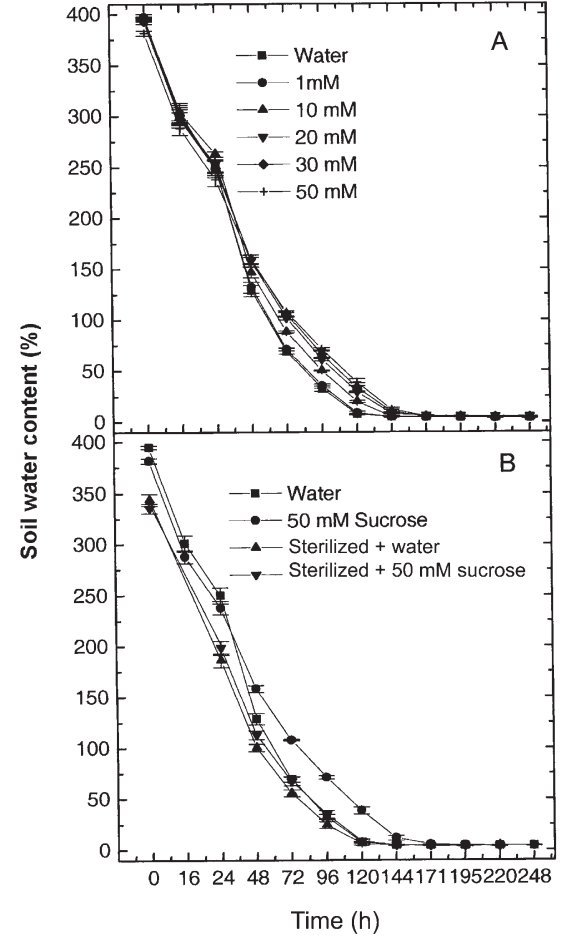

Fig. 4. Changes in moisture content of soilless growing medium (Sunshine Mix I; Fissons, Vancouver, BC, Canada) in 12-cell trays without plants in a growth chamber following a single priming treatment with $8 \mathrm{~mL}$ of water, or 1 to $50 \mathrm{~mm}$ sucrose. Priming with 60, 70, 80, and $90 \mathrm{~mm}$ sucrose produced results similar to $50 \mathrm{~mm}$ and those data were removed to show differences among lower concentrations. Moisture contents were determined from fresh and oven dry weights of medium from three, 12-cell trays for each treatment (A). Moisture contents of medium treated with $50 \mathrm{~mm}$ sucrose or water, with or without autoclaving $\left(134{ }^{\circ} \mathrm{C}, 200 \mathrm{kPa}, 20\right.$-min steam cycle) (B). Error bars represent $\pm \mathrm{SE}$.

Table 1. Soilless growing medium (Sunshine Mix I; Fissons, Vancouver, BC, Canada) water content after treatment with water or $50 \mathrm{~mm}$ sucrose and equilibration at 0.4 or $1.5 \mathrm{MPa}$ on a pressure plate. Values represent three replications of each treatment. Media water content was calculated as a percentage of the soil dry weight (e.g., fresh weight - dry weight/dry weight $\times 100$ after oven drying at $\left.98^{\circ} \mathrm{C}\right)$.

\begin{tabular}{lcc}
\hline & \multicolumn{2}{c}{ Equilibration pressure } \\
\cline { 2 - 3 } Soil treatment & $0.4 \mathrm{MPa}$ & $1.5 \mathrm{MPa}$ \\
\cline { 2 - 3 } & \multicolumn{2}{c}{ Water content $(\%)$} \\
\hline Water & $205 \mathrm{~b}$ & $155 \mathrm{~b}$ \\
$50 \mathrm{mM}$ sucrose & $338 \mathrm{a}$ & $278 \mathrm{a}$ \\
LSD $^{\mathrm{z}}$ & 88 & 34 \\
\hline
\end{tabular}

${ }^{\mathrm{z}}$ Least significant difference at $P<0.05$.

Steam-treating growing medium before priming decreased moisture contents compared with untreated medium during the first $24 \mathrm{~h}$ (Fig. 4B). The moisture contents of primed and nonprimed growing medium were similar after $48 \mathrm{~h}$, indicating that autoclaving negated the increased moisture content previously observed following sucrose priming. Only nonautoclaved growing medium primed with sucrose maintained higher moisture contents between 48 and $120 \mathrm{~h}$ (Fig. 4B).

To compare the priming response in soilless growing medium to other substrates, field soil and acid-washed sand were also primed with sucrose. When sand was primed with 
equivalent volumes of water, or 10 or $50 \mathrm{~mm}$ sucrose solution, moisture contents after an incubation period were similar or lower than water controls (Fig. 5A). Hayter clay-loam soil primed with $50 \mathrm{~mm}$ sucrose had only slightly higher moisture content than the water control between 25 and $135 \mathrm{~h}$ after treatment (Fig. 5B). Vermiculite soilless medium for hydroponic production (tobacco mix) was primed with $50 \mathrm{~mm}$ sucrose and higher medium-moisture contents were obtained between 50 and $140 \mathrm{~h}$ compared with water alone (Fig. 5C).

Soilless growing medium primed with sucrose stained positively with alcian blue, a general stain for carbohydrates, when viewed under a microscope. Blue staining was detected among particles of perlite, peat, and organic matter in samples primed with sucrose solution, but not in those treated with water alone or autoclaved before priming (Fig. 6, A-C).

Bacteria were isolated from the supernatant of primed soilless medium and plated on TSA enriched with $50 \mathrm{~mm}$ sucrose. When colonies producing exudates that stained positively with alcian blue were subcultured on in liquid medium, they produced 2.2 to $3.3 \mathrm{mg}$ dry weight per milliliter per day of putative polysaccharide that was qualitatively analyzed. The predominant neutral monosaccharide isolated from liquidculture component of these polysaccharides was glucose (55\%-65\%) (Fig. 7). The remaining neutral sugars present were variable and depended on the isolate. Arabinose, galactose, mannose, glucosamine, and galactosamine were all detected, but comprised less than $10 \%$ of the neutral sugars (Fig. 7). The chromatographic analyses also revealed the presence of an unknown carbohydrate eluting at retention times

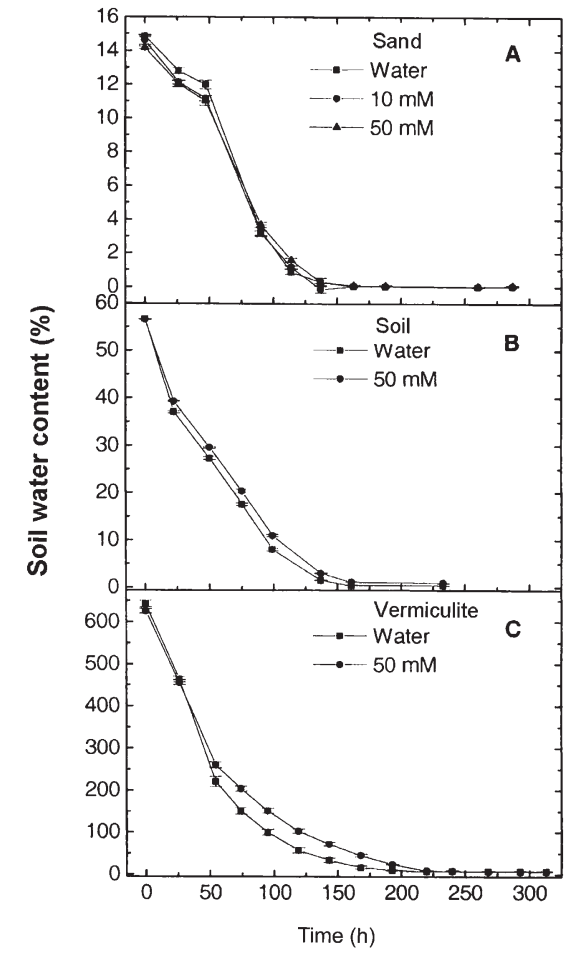

Fig. 5. Comparison of the moisture contents of acid-washed sand in a growth chamber after addition of $8 \mathrm{~mL}$ of water or priming with 10 or $50 \mathrm{~mm}$ sucrose (A) Hayter clay-loam, field soil watered, or primed with $8 \mathrm{~mL}$ of $50 \mathrm{~mm}$ sucrose (B) or vermiculite soilless growing medium watered or primed with $8 \mathrm{~mL}$ of $50 \mathrm{~mm}$ sucrose $(\mathbf{C})$.

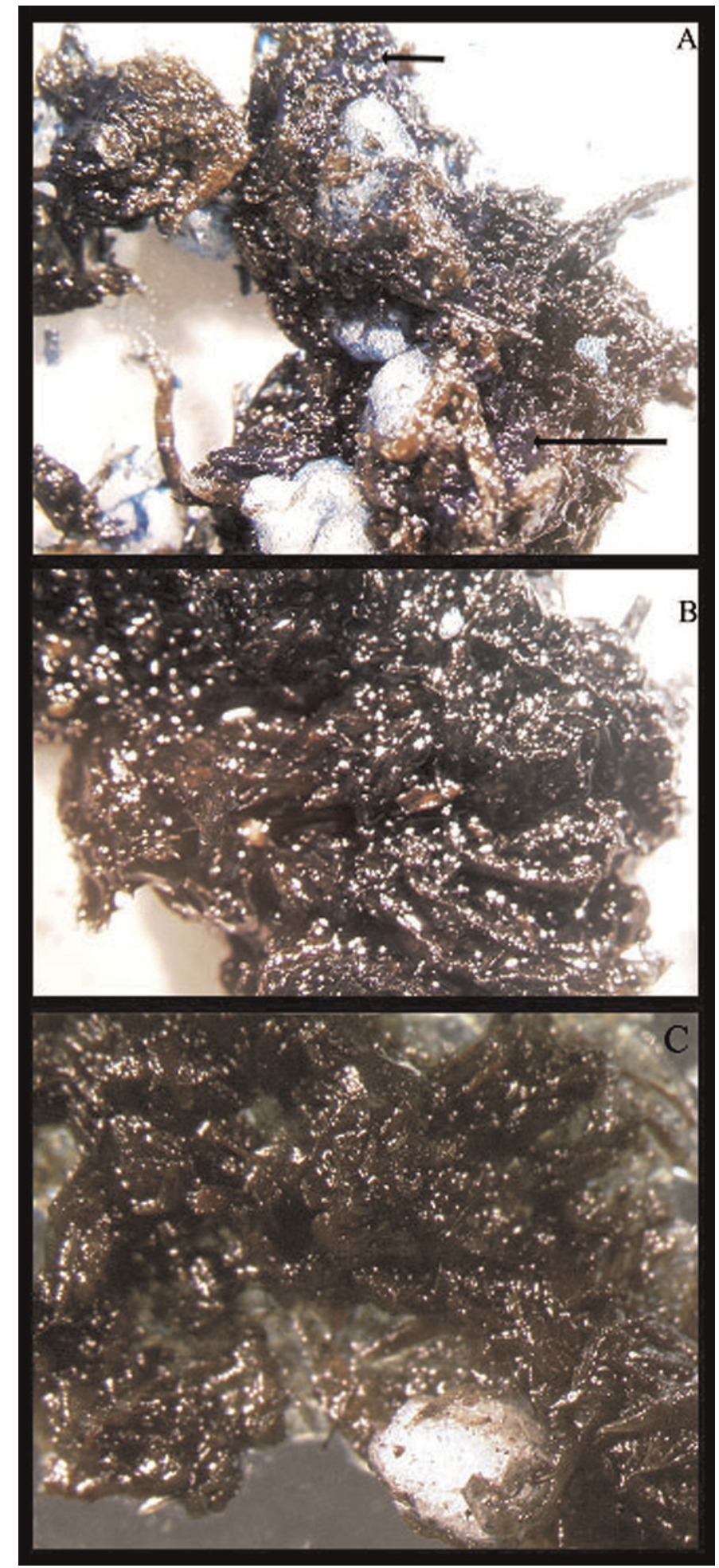

Fig. 6. After watering or priming with $50 \mathrm{~mm}$ sucrose for at least $72 \mathrm{~h}$, samples of soilless growing medium were dried and stained with alcian blue, a polysaccharide-specific stain. Alcian blue staining was apparent among particles of organic matter in sucrose-primed samples (A) $\times 3.2$. Staining was absent in growing medium hydrated with only water $(\mathbf{B}) \times 3$.2. Staining was absent when growing medium was first autoclaved for $20 \mathrm{~min}$ then primed with $50 \mathrm{~mm}$ sucrose for $72 \mathrm{~h}(\mathbf{C}) \times 4.1$. (Please view this paper online at ashs.org to see the image in color.) 


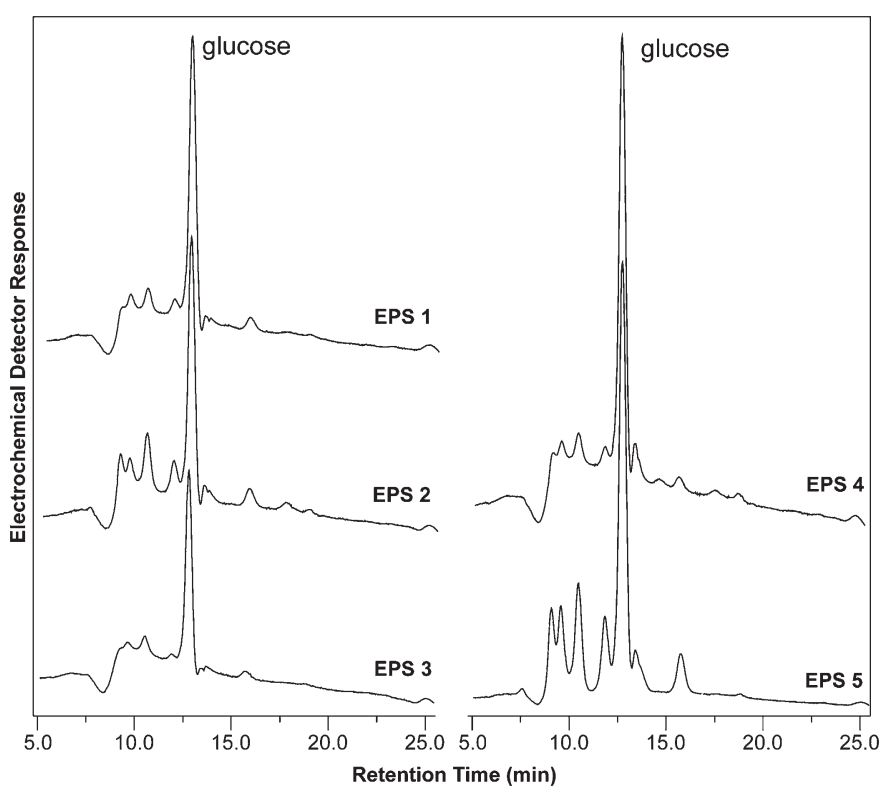

Fig. 7. Extracellular polysaccharides (EPS) chromatograms of neutral monosaccharides isolated from three liquid bacterial cultures from primed soilless growing medium (Sunshine Mix I; Fissons, Vancouver, BC, Canada). Glucose is the predominant monosaccharide, comprising between 55\% and $65 \%$ of the total neutral sugars. Arabinose, galactose, mannose, glucosamine, and galactosamine were also detected, but variability in the levels of these monosaccharides prevented accurate quantification. EPS 1 and 4, and 2 and 5 were replicates of separate biological samples, while EPS 3 was an additional sample.

indicative of uronic acid that did not match galacturonic and glucuronic acid standards.

Sixteen bacteria, including Curtobacterium pussillum, Paenibacillus lautus, Brevundimonas, and 13 Bacillus spp., were cultured, isolated, and genetically identified from primed soilless growing medium (Table 2, Fig. 8). Eleven of the bacteria were gram-positive and rod-shaped (Table 2, Fig. 8).

\section{Discussion}

Trehalose is a nonreducing disaccharide, $\alpha$-D-glucopyranosyl-(1,1)- $\alpha$-D glucopyranoside, and is a common sugar in fungi, bacteria, and invertebrate animals (Almeida et al., 2007). Priming soilless growing medium with trehalose or sucrose slowed medium water loss and delayed wilting of muskmelon transplants (Figs. 1-3). Sugars regulate gene expression and trehalose, in particular, affects gene expression associated with carbohydrate metabolism and plant development (Aeschbacher et al., 2000; León and Sheen, 2003; Smeekens, 2000). Transgenic plants expressing the Escherichia coli or Saccharomyces cerevisiae genes for trehalose synthesis not only exhibit increased drought tolerance (Holmström et al., 1996; PilonSmits et al., 1998; Romero et al., 1997), but also exhibit strong developmental alterations, such as stunted growth (Goddijn et al., 1997; Romero et al., 1997).

Plant $\psi_{\mathrm{S}}$ measured by porometry and moisture sorption isotherms (Bell and Labuza, 2000) were not changed after soilless growing medium was primed with $50 \mathrm{~mm}$ sucrose (not shown). The mean $\psi_{\mathrm{S}}$ of sucrose-primed growing medium solution was $-0.12 \mathrm{MPa}$ measured by osmometry. This suggests that the delay in the onset of wilting resulted from improved
Table 2. Bacterial colonies isolated from soilless growing medium (Sunshine Mix I; Fissons, Vancouver, BC, Canada) and cultured in tryptic soy agar enriched with $50 \mathrm{~mm}$ sucrose. 16S rRNA amplification products were sequenced and database matches are listed below. Relationships among bacteria are summarized in Fig. 8.

Sample

\begin{tabular}{lccc} 
identifier & Gram stain & Appearance & 16S RNA match \\
\hline WBS1 & Unknown & Unknown & Curtobacterium pusillum
\end{tabular}

WBS2 Positive Rod Bacillus subtilis subtilis

WBS3 Positive Rod Bacillus subtilis subtilis

WBS4 Positive Rod Bacillus subtilis subtilis

WBS5 Positive Rod Bacillus pumilus

WBS6 Positive Rod

WBS7 Positive Rod

WBS8 Positive Rod

WBS10 Positive Rod

WBS11 positive Rod

WBS12 Positive Rod

WBS13 Positive Rod

WBS15 Unknown Unknown Bacillus mojavensis

WBS16 Unknown Unknown Brevundimonas sp.

WBS18 Unknown Unknown Bacillus circulans

medium retention of plant-available water and not plant-osmotic adjustment because priming increased moisture retention without plants present (Fig. 4). Oven drying and pressure-plate analysis confirmed that sucrose-treated growing medium held significantly more water compared with untreated samples (Fig. 3A; Table 1). Optimum sucrose-priming concentrations ranged from 30 to $50 \mathrm{~mm}$ (Fig. 2, 4A). Wilting and abnormal development were observed in muskmelon, marigold (Tagetes patula), and alyssum (Lubularia maritime) plants at sucrose concentrations $>70 \mathrm{~mm}$ (Faltenovitch and Welbaum, 2008). Priming acid-washed sand (Fig. 5A) and autoclaved soilless growing medium (Fig. 4B) failed to improve moisture retention or cause positive staining with alcian blue, suggesting that the positively stained matter was of microbial origin and not the direct effect of sucrose amendments (Fig. 6).

The lag phase in moisture retention during the first $24 \mathrm{~h}$ after treatment was also consistent with a biological process (Fig. 4). Furthermore, the moisture-holding capacity of vermiculitebased growing medium and Hayter loam soil was only slightly increased by sucrose priming, illustrating that the dramatic improvement in soil-moisture retention in sphagnum-based soilless growing medium was not a universal response and was unique to Sunshine Mix I soilless growing medium (Fig. $5 \mathrm{C})$.

Light micrographs of medium revealed alcian blue staining for carbohydrate only in sugar-primed soilless growing medium, suggesting that improved soil-moisture holding capacity was related to the positive staining matter randomly scattered among medium particles (Fig. 6). The transformation of loose soilless growing medium into solid masses that resisted crumbling (Fig. 2, inset) is consistent with the observation that the carbohydrate-positive staining material was serving as hydrophilic glue to solidify particles when dried (Fig. 6A).

Thirteen of the 16 colonies cultured on agar medium supplemented with sucrose from soilless growing medium leachate were Bacillus spp. (Table 2, Fig. 8). Biofilm production by Curtobacterium pussillum, Paenibacillus lautus, 


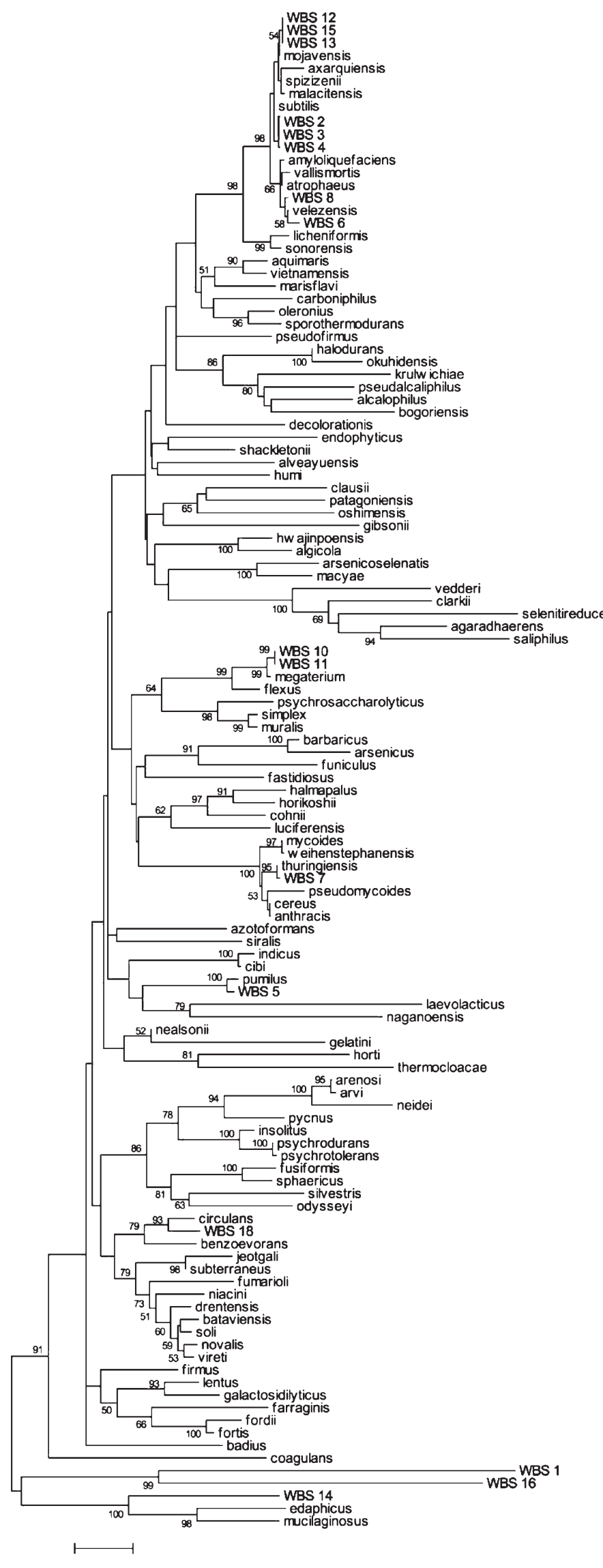

and Brevundimonas is less common than in Bacillus spp., which are common biofilm producers. For example, a complex glucose-based polysaccharide polymer is produced by $B$. megaterium (Bishop and White, 1993; Gandhi, et al., 1997). The polymer produced in solution cultures isolated from primed medium was predominately glucose, consistent with the hypothesis that $B$. megaterium contributed to biofilm production in primed soilless growing medium (Fig. 7). The optimal growth for B. megaterium in culture was obtained using $5 \%(\mathrm{w} / \mathrm{v})$ date (Phoenix dactylifera) syrup or beet (Beta vulgaris) molasses supplemented with $\mathrm{NH}_{4} \mathrm{Cl}$ (Omar et al., 2001). B. megaterum has other documented agricultural benefits, such as an ability to solubilize inorganic phosphate (Cakmakci et al., 1992) and suppress Rhizoctonia root rot of soybean (Glycine max) (Zheng and Sinclair, 2000).

The production of biofilms has been characterized in other prokaryotes, including the Pseudomonads (Singh and Fett, 1995). The terrestrial cyanobacterium Nostoc commune excretes large amounts of glucan polysaccharide with unusual properties, including maintenance of secreted enzymes in an active state during long-term, air-dried storage, and accommodation of rapid biophysical and physiological changes upon rehydration (Helm et al., 2000).

The biofilm reported here has properties in common with glomalin, a fungal protein produced by vesicular-arbuscular mycorrhiza (Wright and Upadhyaya, 1996). Glomalin, produced by fungi in the order Glomales, may account for as much as $27 \%$ of total carbon in some soils (Rillig et al., 2001). Glomalin is thought to maintain soil structure and to promote water-holding capacity, proper aeration, and root growth in certain soils (Rillig et al., 2002). Soil microbial extracellular polysaccharides may be an important factor affecting soil structure in cultivated soils (Rillig et al., 2001; Roberson et al., 1995).

The benefits of sugar amendments to soils and compost have been reported for years (for example, Story, 1939). Molasses (syrup produced during sugar refining) has been used to hasten decomposition of compost and by agriculturalists as a soil amendment. Soils amended with molasses had greater moisture retention in a papaw (Asimina triloba) field study in Australia, although specific mechanisms were not investigated (Vawdrey et al., 2002). The possible benefits of directly priming soils with sucrose or other sugars with the express intent of stimulating beneficial soil microbes has not been fully evaluated (Schenck, 2001, Welbaum et al., 2004).

Because Bacillus is a gram-positive, nonpathogenic bacterium that forms resting spores and extracellular carbohydrates, the potential exists for priming certain soil types directly with specific carbon sources or indirectly with cover crops capable of simulating microbial colonies to improve soil characteristics through biofilm production. In the current study, the greatest effect occurred in commercial sphagnum-based soilless growing medium used primarily for greenhouse production of bedding plants and high-value crops. Adding sugar to sand,

Fig. 8. Sixteen bacterial colonies isolated from $50 \mathrm{mM}$ sucrose-treated soilless growing medium (Sunshine Mix I; Fissons, Vancouver, BC, Canada) with enhanced moisture retention were genetically identified based on 16S rRNA sequence homology. The neighbor-joining tree shows interspecies relationships among sample matches. Distances can be estimated by summing horizontal differences using the $\mathrm{N}$-join distance key at the bottom of the diagram. Unknown samples are coded WBS and are referenced in Table 2. 
field soil, or vermiculite-based growing medium produced a slight or no improvement in soil-moisture retention (Fig. 5). Similarly, inoculating field soils, or other brands of soilless growing media, with various combinations of bacteria from Table 2 and priming with sucrose did not increase moisture retention to the extent reported in Figs. 1, 3, and 4 (K. Woods, personal communication). This indicates that the Sunshine Mix I soilless growing medium composition (e.g., $\mathrm{pH}$, mineral content, and high organic matter) along with its microbial composition offered unique conditions for biofilm production. Culture-dependent detection methods for fungi and bacteria may give a biased, incomplete picture of microbial communities (Pace, 1997) so that bacteria other than those in Table 2 may have been responsible for biofilm production because only $10 \%$ of the bacterial and fungal populations can be cultured (Kirk et al., 2004, Sakai et al., 2004). Nonculturable, DNAbased microbial detection techniques may be required to provide additional qualitative information about organisms contributing to biofilm production in soilless growing medium primed with sucrose or trehalose before biofilms can be produced in culture or other soils. This work illustrates that soilless growing media with certain microbial composition can be successfully primed with small concentrations of sucrose or trehalose to simulate biofilm production, thus improving moisture-holding capacity and transplant production under moisture stress conditions.

\section{Literature Cited}

Aeschbacher, R.A., A. Wingler, T. Fritzius, D. Brodmann, T. Boller, and A. Wiemken. 2000. Trehalose induces the ADP-glucose pyrophosphorylase gene, ApL3, and starch synthesis in Arabidopsis. Plant Physiol. 124:105-114.

Almeida, A.M., L.A. Cardoso, D.M. Santos, J.M. Torne, and P.S. Fevereiro. 2007. Trehalose and its applications in plant biotechnology. In Vitro Cell. Dev. Biol. Plant 43:167-177.

Bell, L.N. and T.P. Labuza. 2000. Practical aspects of moisture sorption isotherm measurement and use. 2nd ed. AACC Egan Press, Egan, MI.

Bishop, A.H. and P.J. White. 1993. Composition of an unusual accessory polymer containing N- lactyl-3-amino-3, 6-dideoxyhexose from walls of Bacillus megaterium Ncib 7581. J. Gen. Microbiol. 139:2731-2738.

Blagodatskaya, E. and Y. Kuzyakov. 2008. Mechanisms of real and apparent priming effects and their dependence on soil microbial biomass and community structure: Critical review. Biol. Fertil. Soils 45:115-131.

Bruegger, B.B. and N.T. Keen. 1979. Specific elicitors of glyceollin accumulation in the Pseudomonas glycinea soybean host-parasite system. Physiol. Plant Pathol. 15:43-51.

Cakmakci, R., F. Kantar, and O.F. Algur. 1992. Sugar beet and barley yields in relation to Bacillus polymyxa and Bacillus megaterium var. phosphaticum inoculation. J. Plant Nutr. Soil Sci. 162:437-442.

Chanway, C.P., L.M. Nelson, and F.B. Holl. 1988. Cultivar-specific growth promotion of spring wheat (Triticum aestivum L.) by coexistent Bacillus species. Can. J. Microbiol. 34:925-929.

Conrath, U., G.J.M. Beckers, V. Flors, P. García-Agustín, G. Jakab, F. Mauch, M.-A. Newman, C.M.J. Pieterse, B. Poinssot, M.J. Pozo, A. Pugin, U. Schaffrath, J. Ton, D. Wendehenne, L. Zimmerli, and B. Mauch-Mani. 2006. Priming: Getting ready for battle. Mol. Plant Microbe Interact. 19:1062-1071.

Faltenovitch, S. and G.E. Welbaum. 2008. Controlling vegetable transplant height with managed osmotic stress. Acta Hort. 782: 293-298.

Gandhi, H.P., R.M. Ray, and R.M. Patel. 1997. Exopolymer production by Bacillus species. Carbohydrate Polymers 34:323-327.
Goddijn, O.J.M., T.C. Verwoerd, E. Voogd, R.W.H.H. Krutwagen, P.T.H.M. de Graaf, J. Poels, K. van. Dun, A.S. Ponstein, B. Dammn, and J. Pen. 1997. Inhibition of trehalase activity enhances trehalose accumulation in transgenic plants. Plant Physiol. 113:181-190.

Grayston, S.J., S. Wang, C.D. Campbell, and A.C. Edwards. 1998. Selective influence of plant species on microbial diversity in the rhizosphere. Soil Biol. Biochem. 30:369-378.

Hawes, M.C. and L.A. Brigham. 1992. Impacts of root border cells on microbial populations in the rhizosphere. Adv. Plant Pathol. 8:119148.

Hawes, M.C., L.A. Brigham, F. Wen, H.H. Woo, and Y. Zhu. 1998. Function of root border cells in plant health: Pioneers in the rhizosphere. Annu. Rev. Phytopathol. 36:311-327.

Helm, R.F., Z. Huang, H. Leeson, D. Edwards, B. Peery, and M. Potts. 2000. Structural characterization of the released polysaccharide of desiccation-tolerant Nostoc commune DRH-1. J. Bacteriol. 182:974982.

Holmström, K.-O., E. Mäntylä, B. Welin, A. Mandal, E.T. Palva, O.E. Tunnela, and J. Londesborough. 1996. Drought tolerance in tobacco. Nature 379:683-684.

Hoyle, F.C., D.V. Murphy, and P.C. Brookers. 2008. Microbial response to the addition of glucose in low-fertility soils. Biol. Fertil. Soils 44:571-579.

Karlen, D.L., M.J. Mausbach, J.W. Doran, R.G. Cline, R.F. Harris, and G.E. Schuman. 1997. Soil quality: A concept, definition, and framework for evaluation. Soil Sci. Soc. Amer. J. 61:4-10.

Kavino, M., S. Harish, N. Kumar, D. Saravanakumar, T. Damodaran, K. Soorianathasundaram, and R. Samiyappan. 2007. Rhizosphere and endophytic bacteria for induction of systemic resistance of banana plantlets against bunchy top virus. Soil Biol. Biochem. 39:1087-1098.

Kelliher, F.M., M.M. Barbour, and J.E. Hunt. 2005. Sucrose application, soil microbial respiration and evolved carbon dioxide isotope enrichment under contrasting land uses. Plant Soil 268:233-242.

Kirk, J.L., L.A. Beaudette, M. Hart, P. Moutoglis, J.N. Klironomos, H. Lee, and J.T. Trevors. 2004. Methods of studying soil microbial diversity. J. Microbiol. Methods 58:169-188.

Koch, K.E. 1996. Carbohydrate modulated gene expression in plants. Annu. Rev. Plant Physiol. Plant Mol. Biol. 47:509-540.

Kolbert, C.P. and D.H. Pershing. 1999. Ribosomal DNA sequencing as a tool for identification of bacterial pathogens. Curr. Opin. Microbiol. 2:299-305.

León, P. and J. Sheen. 2003. Sugar and hormone connections. Trends Plant Sci. 8:110-116.

Lugtenberg, B.J.J., L. Dekkers, and G.V. Blomberg. 2001. Molecular determinants of rhizosphere colonization by pseudomonas. Annu. Rev. Phytopathol. 39:461-490.

Marschner, P., D. Crowley, and C.H. Yang. 2004. Development of specific rhizosphere bacterial communities in relation to plant species, nutrition and soil type. Plant Soil 261:199-208.

Mondini, C., M.L. Cayuela, M.A. Sanchez-Monedero, A. Roig, and P.C. Brookes. 2006. Soil microbial biomass activation by trace amounts of readily available substrate. Biol. Fertil. Soils 42:542-549.

Nowak, J. and V. Schulaev. 2003. Priming for transplant stress resistance in in vitro propagation. In Vitro Cell. Dev. Biol. Plant 39:107-124.

Omar, S., A. Rayes, A. Eqaab, I. Voss, and A. Steinbuchel. 2001. Optimization of cell growth and poly(3-hydroxybutyrate) accumulation on date syrup by a Bacillus megaterium strain. Biotechnol. Lett. 23:1119-1123.

Pace, N.R. 1997. A molecular view of microbial diversity and the biosphere. Science 276:734-740.

Pankhurst, C.E., B.M. Doube, and V.V.S.R. Gupta. 1997. Biological indicators of soil health. CAB International, Wallingford, UK.

Patel, J.B., D.G.B. Leonard, X. Pan, J.M. Musser, R.E. Bergman, and I. Nachamkin. 2000. Sequence-based identification of mycobacterium species using the MicroSeq 500 16S rDNA, bacterial identification system. J. Clin. Microbiol. 38:246-251. 
Pilon-Smits, E.A.H., N. Terry, T. Sears, H. Kim, A. Zayed, S. Hwang, K. van Dun, E. Voogd, T.C. Verwoerd, R.W.H.H. Krutwagen, and O.J.M. Goodijn. 1998. Trehalose-producing transgenic tobacco plants show improved growth performance under drought stress. J. Plant Physiol. 152:525-532.

Powell, K.R., J.O. Hendley, K.E. Pohl, A. Freidberg, and W.A. Volk. 1982. Quantitation of acidic capsular polysaccharides by alcian blue binding. Anal. Biochem. 119:31-37.

Rillig, M.C., F. Wright, and V.T. Eviner. 2002. The role of arbuscular mycorrhizal fungi and glomalin in soil aggregation: Comparing effects of five plant species. Plant Soil 238:325-333.

Rillig, M.C., F. Wright, K.A. Nichols, W.F. Schmidt, and M.S. Torn. 2001. Large contribution of arbuscular mycorrhizal fungi to soil carbon pools in tropical forest soils. Plant Soil 233:167-177.

Roberson, E.B., S. Sarig, C. Shennan, and M.K. Firestone. 1995. Nutritional management of microbial polysaccharide production and aggregation in an agricultural soil. Soil Sci. Soc. Amer. J. 59:15871594.

Romero, C., J.M. Belles, J.L. Vaya, R. Serrano, and F.A. CulianezMacia. 1997. Expression of the yeast trehalose-6-phosphate synthase gene in transgenic tobacco plants: pleiotropic phenotypes include drought tolerance. Planta 201:293-297.

Ryan, P.R., E. Delhaize, and D.L. Jones. 2001. Function and mechanism of organic anion exudation from plant roots. Annu. Rev. Plant Physiol. Plant Mol. Biol. 52:527-560.

Sakai, M., A. Matsuka, T. Komura, and S. Kanazawa. 2004. Application of a new PCR primer for terminal restriction fragment length polymorphism analysis of the bacterial communities in plant roots. J. Microbiol. Methods 59:81-89.

Schenck, S. 2001. Molasses soil amendment for crop improvement and nematode management. Hawaii Agr. Res. Ctr. Veg. Rpt. 3, Aiea, HI. Schneckenberger, K., D. Demin, K. Stahr, and Y. Kuzyakov. 2008. Microbial utilization and mineralization of [14C]glucose added in six orders of concentration to soil. Soil Biol. Biochem. 40:1981-1988.

Shen, Z.X. and G.E. Welbaum. 2004. Exogenous trehalose inhibits hypocotyl elongation of alyssum and muskmelon seedlings. Acta Hort. 631:135-139.
Siciliano, S.D., C.M. Theoret, J.R. de Freitas, P.J. Hucl, and J.J. Germida. 1998. Differences in the microbial communities associated with the roots of different cultivars of canola and wheat. Can. J. Microbiol. 44:844-851.

Singh, S. and W.F. Fett. 1995. Stimulation of exopolysaccharide production by fluorescent pseudomonads in sucrose media due to dehydration and increased osmolarity. FEMS Microbiol. Lett. 130:301-306.

Smeekens, S. 2000. Sugar-induced signal transduction in plants. Annu. Rev. Plant Physiol. Plant Mol. Biol. 51:49-81.

Story, C.G. 1939. The lasting effects of molasses used as fertilizer. Queensland Agr. J. 52:310-311.

Talaga, P., S. Vialle, and M. Moreau. 2002. Development of a highperformance anion-exchange chromatography with pulsed-amperometric detection based quantification assay for pneumococcal polysaccharides and conjugates. Vaccine 20:2474-2484.

Vawdrey, L.L., T.M. Martin, and J. DeFaveri. 2002. The potential of organic and inorganic soil amendments, and a biological control agent (Trichoderma sp.) for the management of Phytophthora root rot of papaw in far northern Queensland. Australas. Plant Pathol. 31:391-399.

Wardle, D.A. 2002. Communities and ecosystems: Linking the aboveground and belowground components. Princeton University Press, Princeton, NJ.

Welbaum, G.E., A.V. Sturz, Z. Dong, and J. Nowak. 2004. Fertilizing soil microorganisms to improve productivity of agroecosystems. Crit. Rev. Plant Sci. 23:175-193.

Wright, S.F. and A. Upadhyaya. 1996. Extraction of an abundant and unusual protein from soil and comparison with hyphal protein of arbuscular mycorrhizal fungi. Soil Sci. 161:575-586.

Yunusa, I.A.M. and P.J. Newton. 2003. Plants for amelioration of subsoil constraints and hydrological control: The primer-plant concept. Plant Soil 257:261-281.

Zheng, X.Y. and J.B. Sinclair. 2000. The effects of traits of Bacillus megaterium on seed and root colonization and their correlation with the suppression of Rhizoctonia root rot of soybean. BioControl $45: 223-243$. 